\title{
Influence of Head Teachers' Performance Monitoring on Participation of Female Students with Physical Disabilities in Primary Schooling in Mandera County, Kenya
}

\author{
Aftin Kullow DUBE, , Joseph Gachingua MUNGAI and Peter Muchanje NYAGA. \\ Aftin Kullow Dube- Kenyatta University aftinkullow@gmail.com \\ Joseph Gachigua Mungai- Kenyatta University mungai.joseph@ku.ac.ke \\ Peter Munchanje Nyaga- Kenyatta University muchanje.peter@ku.ac.ke
}

\begin{abstract}
Monitoring of performance is measured by the examination outcome from the mock results which helps head teachers using empirical facts, make educated choices about program operations, service delivery, and program efficacy. The researcher worked towards addressing the influence of head teachers' monitoring of performance on participation of female students with physical disabilities in primary school education. This study, which included 68 head teachers and 990 pupils from special schools in Mandera County, used a descriptive sample polling design with a total population of 1058 respondents. Students were picked at random, with the exception of the head teachers, who were purposively chosen. After utilizing the Krejcie and Morgan (1970) formula to assist pick sample size for this study, both principals and students were proportionately selected. According to Krejcie and Morgan (1970) statistics, a population of 990 children forced a sample size of 277 children, and a population of 68 head teachers necessitated a sample size of 58 head teachers resulting to a total sample size of 335 respondents. Questionnaires, content analysis guides, and focus group discussion guides were created as part of the study process. This study used a variety of research instruments, such as questionnaires, content analysis guides, and focus group discussion guides, to map out the data needed from a variety of sources. To verify authenticity, data collecting instruments were triangulated. The data collecting instruments were created in consultation with university supervisors to assure authenticity. This study employed a split-half reliability test to determine the questionnaire's reliability. As stated in the aims, quantitative data was analyzed using descriptive statistics such as frequencies, means, and standard deviation, while qualitative data was analyzed for common themes related to specific research parameters. The findings revealed that there was a 17.5 percent increase in participation of female pupils with physical disabilities for every unit increase in head teachers' performance monitoring.
\end{abstract}

Keywords: Head teachers, Performance, Monitoring, Female Students, Disabilities, Primary Schools, Kenya. DOI: $10.7176 /$ RHSS/12-4-02

Publication date: February $28^{\text {th }} 2022$

\section{INTRODUCTION}

Background to the Study

It is estimated that there are between 93 million and 150 million disabled children (0-14 years) worldwide (World Population Prospects, 2008). Historically, many children and people with physical disabilities have been denied access to public schooling. In most nations, the first attempts to give teaching or training were often made by autonomous special schools, which typically addressed individual disabilities, such as blind schools. All governments should prioritize ensuring that children, especially girls with disabilities, get a high-quality education in an inclusive environment (Eide, Rooy \& Loeb, 2006). Participation in shared governance by both girls with physical disabilities and staff increases acceptability and support for policy decisions; in accordance with this viewpoint, this study views head teachers' monitoring of students' academic performances as a management practice and that of the staff as predictors of academic participation, particularly for girls with physical disabilities.

According to Ballard et al., (2010), monitoring of performance will be monitored by the examination outcome from the mock results, which allows head teachers make educated decisions regarding program management, service delivery, and program efficacy using empirical data. In their examination of Adventist secondary schools in Ranen Conference in Migori County, Allida, Olela, Ogwari, and Minja (2018) revealed that optimal instructional supervision approaches provide understanding and abilities that a 21 st century instructional leader desperately needs. Even though the frequency, goal, and manner varied greatly from one organization to the next, the data demonstrated that at least monitoring was taking place in schools.

In 2006 , just $10 \%$ of visually impaired children aged 7 to 12 were enrolled in kindergarten, whereas $40 \%$ of autistic females were enrolled, which was only significantly lower than the attendance rate for non-disabled children in Burkina Faso (UNESCO, 2010). According to Porter (2009), there were 300 disabled females enrolled in elementary and secondary schools, and 9 in private high schools. This was due to a lack of efficient 
management practices in these schools to promote and encourage the attendance of these students. According to research, teachers were designated as selected change leaders from the 1990s to the beginning of the 2000s. Head teachers were formerly classed as transaction leaders, but according to Hsiao et al. (2013), they are now classified as supervising practitioners (Huff, et al, 2013; Krasnoff, 2015; Mendels \& Mitgang, 2013). This classification was important in order to identify the best management methods that are required to increase participation in these institutions, notably for the girls with physical limitations.

Three paradigms have been adopted locally in research on elements that impact school pupils' academic participation. Scholarly achievement, according to one school of thinking, is the outcome of logical variables at home and at school (Gatumu et al., 2012; Nyagosia, 2011). A second set of research investigates how factors such as self-impediment, scholastic inspiration, and confidence impact academic participation (Mutweleli, 2014; Okoko, 2012; Wawire, 2010). A third set of research examines how scholastic participation is influenced by a combination of relevant and individual factors (Ongowo \& Hungi, 2014). Opini (2018), on the other hand, has addressed barriers to women with disabilities in Kenyan universities. Handicapped students continue to enroll in universities and complete their studies; nonetheless, the number of disabled women participating in higher education remains small. All of the research above point to distinct variables impacting female students' engagement in secondary school and higher education, but little is known regarding head teachers' monitoring of performance influence participation of female students with physical disabilities in primary school.

Mandera County in Kenya is noted for having one of the poorest populations in the country, with more than $60 \%$ of the people living in poverty (Ibrahim \& Orodho, 2014). This is the situation for the youngsters of the North Eastern nation. Any one of these issues speaks to a number of challenges that females, especially those with physical impairments, confront in their educational pursuits. Monitoring performance by head teachers can assist in eliminating issues such as inadequate organization and low standards for everyday comforts, which can impair students' academic success (Njoroge and Nyabuto, 2014; Kiprop, 2012). Background evidence suggests that a variety of factors may impact the engagement of disabled students in primary school education. The current study, on the other hand, aimed to see how the performance monitoring of the head teacher affected the engagement of female students with physical impairments in special primary schools in Kenya's Mandera County

\section{Statement of The Problem}

Female students with impairments are frequently kept hidden from view, and girls with disabilities are only seen in groups at social gatherings or government meetings. As a consequence of the above, it is apparent that female learners with physical impairments who wish to achieve financial and personal independence must be able to receive an education and overcome a variety of academic challenges. Despite the fact that many governments pledge to provide services to all school-aged children regardless of gender, special education has received little attention in regard to improving the low enrolment and retention of impaired female learners in primary schools. The study's main point is that school administrators must understand resources and methods in head teachers' performance monitoring and its influence on female students with physical disabilities participation in primary school. There have been studies on how to monitor the performance of head teachers. However, there is limited research on the impact of head teachers' performance monitoring on the participation of girls with physical impairments in primary schooling. This investigation was prompted by the knowledge information gap. The purpose of this study was to examine the impact of head teachers' performance monitoring on participation of female learners with physical disabilities in primary education in Mandera County, Kenya.

\section{Purpose and Objectives of The Study}

The main purpose of the study was to determine head teachers' monitoring of performance influence participation of female students with physical disabilities in primary school education in Mandera county.

The study aimed at achieving the following objectives:

i. To establish levels of involvement of teachers, parents, and school management committees' in performance of female students with physical disability.

ii. To determine if head teachers' monitoring of performance influence participation of female students with physical disabilities in primary school education in Mandera County.

\section{Research Questions}

i. What is the levels of involvement of teachers, parents, and school management committees' in performance of female students with physical disability?

ii. To what extent do head teachers' monitoring of performance influence participation of female students with physical disabilities in primary school education in Mandera County? 


\section{Hypothesis of The Study}

$\mathrm{H}_{01}$ : There is no significant relationship between head teachers' monitoring of performance and participation of female students with physical disabilities in primary school education in Mandera County.

\section{RESEARCH METHODOLOGY}

In this section, the research approach, design, population, sample size and sampling techniques, methods of data collection and analysis have been addressed.

\section{Research Design}

A descriptive survey analysis design was employed in this study, which is a sort of survey that is commonly used when the research population is big and the data is collected all at once. Descriptive survey analysis involves collecting data on several times over a period of time in order to create a body of measurable data connected to two or three variables, which is then analyzed to uncover a pattern (Bryman, 2004). It blends quantitative and qualitative investigations in terms of data gathering, interpretation, and introduction. The design may frequently be utilized as an analytical research that investigates a current occurrence in its real-life environment when the differences between phenomena and context are not clearly obvious and many sources of data are utilized (Mugenda \& Mugenda, 2003; Orodho, Nzabalirwa, Odundo, Waweru \& Ndayambaje,2016)). The extensive survey design is highly effective if the researcher wants to have a complete understanding of the study environment and procedures. The capacity to analyze occurrences in real-world contexts is one of this design's main advantages.

\section{Target Population, Sampling Technique and Sample Size}

A target population is a group of people or businesses who share certain characteristics (Kothari, 2004). There were 68 special public elementary schools investigated in Mandera County. There were 990 pupils (567 boys and 423 females) and 68 professors in the school (Mandera County Education Office, 2017). The researchers employed both purposive and simple random sampling methods to get the sample for the study. Head teachers in Mandera County secondary schools were chosen for this study because they are regarded to have a wealth of expertise on management methods that may affect the involvement and academic successes of female students with disabilities. Both the head teachers and the pupils were proportionately picked based on the population size of each sub county. In this study, the majority of head teachers were interviewed for qualitative data using deliberate sampling. To guarantee that each respondent had a reasonable chance of being picked for the sample, the students were chosen at random. Simple random sampling includes identifying the population, naming each individual or segment of the population, and picking individuals at random. As a result, random sampling was the most effective method for obtaining a representative sample when opposed to other methods. A population of 990 students demanded a sample size of 277 pupils, while a population of 68 head teachers necessitated a sample size of 58 head teachers, totaling 335 respondents, according to the chart by Krejcie and Morgan (1970). The study employed a $90 \%$ confidence level and a maximum degree of variation of $50 \%(0.5)$, which indicates the population's estimated proportion of a trait. The ten percent accuracy criterion was set as the goal ( Orodho,2017)..

\section{Data Collection Instruments}

To map out the data required from a variety of sources in this report, various research instruments such as questionnaires, content review schedules, and focus group discussions guides were created. The questionnaires were sent to the head teachers, who then met with the researcher to discuss the problem and agree on how to complete the questionnaires. The respondents were told that this was not an examination and that they could answer as frankly as possible.( Orodho,2017). After an agreed-upon day, the researcher retrieved the completed questionnaires. The pupils in each of the sampled classes from educational zones were given FGD guides. One focus group included students from grades one through eight. It was possible to capture a variety of perspectives by mixing students from different levels. The researcher used collected textbooks from libraries and other academic sources to triangulate the observations from these instruments.

\section{Data Analysis}

The data was cleaned and sorted before it was processed and inspected. As indicated in the goals, quantitative data was evaluated using descriptive statistics such as frequencies, means, and standard deviation. Data was reviewed at several times during the data collecting phase as well as at the end of the activity. Quantitative data was coded on computers, then evaluated and the findings shown using percentages and frequency tables ( Orodho, Ampofo, Bizimana \& Ndayambaje, 2016). The frequency counts of the replies were then utilized to generate information on the informants who had taken part in the analysis, as well as to display the general pattern of findings for the many variables under investigation. The qualitative data was analyzed for general 
patterns relating to different research characteristics such as head teachers' use of participatory decision-making, leadership styles, and communication abilities on student involvement. Evaluation notes, course books, instruction manuals, lecture or meeting papers, and minutes of reports relating to head teachers' management and its effect on student performance of female pupils with physical disabilities were among the records examined.

\section{RESULTS AND DISCUSSION}

\section{Results}

Involvement of Significant Actors in Performance of Female Learners with Physical Disabilities

The study's goal was to see if head teachers' performance monitoring affected female students with physical impairments' involvement in primary school education in Mandera County. As a result, the head teachers were asked to assess how much they agreed with different assertions about head teachers' performance monitoring. The identified indicators upon which head teachers monitored performance included: teacher's involvement in students' performance, pupils' involvement in their own performance, parents' involvement and school management committees' involvement in performance of female students with physical disability. The responses were given following Likert scale of 1-5 based on whether they strongly disagreed or agreed as guided in the questionnaire. The findings are as shown in Table 1

Table 1: Teacher Involvement in Performance

\begin{tabular}{|c|c|c|c|c|c|c|c|}
\hline Statement & $\begin{array}{l}\text { Strongly } \\
\text { Disagree }\end{array}$ & Disagree & Neutral & Agree & $\begin{array}{l}\text { Strongly } \\
\text { Agreed }\end{array}$ & Mean & SD \\
\hline $\begin{array}{l}\text { Teachers are involved in } \\
\text { performance }\end{array}$ & $1.1 \%$ & $3.0 \%$ & $17.8 \%$ & $35.1 \%$ & $43.0 \%$ & 4.2 & 0.89 \\
\hline Pupil involvement & $5.4 \%$ & $6.2 \%$ & $17.4 \%$ & $43.5 \%$ & $27.5 \%$ & 3.81 & 1.01 \\
\hline Parents involvement & $8.4 \%$ & $13.9 \%$ & $27.6 \%$ & $32.5 \%$ & $17.6 \%$ & 3.37 & 1.17 \\
\hline $\begin{array}{l}\text { School } \\
\text { involvement }\end{array}$ & $3.1 \%$ & $4.6 \%$ & $12.4 \%$ & $37.7 \%$ & $42.2 \%$ & 4.11 & 0.98 \\
\hline Total & $4.5 \%$ & $6.9 \%$ & $18.8 \%$ & $37.2 \%$ & $32.6 \%$ & 3.87 & 1.01 \\
\hline
\end{tabular}

As depicted in Table 1, majority of head teachers agreed that teachers were involved in performance of their female students with physical disabilities in their respective schools $(\mathrm{M}=4.2, \mathrm{SD}=0.89)$, and monitored them. In terms of pupils' involvement, the respondents agreed with a $(\mathrm{M}=3.81, \mathrm{SD}=1.01)$. The findings also showed that parents were involved in the organizing function including defining and structuring roles among others $(\mathrm{M}=3.37$, $\mathrm{SD}=1.17$ ) and school committee teachers' involvement in designing school programmes in their respective schools were highly supported by head teachers $(M=4.11, S D=0.98)$. As shown in the findings of this study, principals succeeded in involving teachers in designing school programmes. Therefore, head teachers' performance monitoring as management practice relied heavily on teachers' involvement in participation of female pupils with physical disabilities. The study findings revealed that teachers were directly involved in monitoring the performance of female pupils with physical disabilities. These findings demonstrate that pupils who contribute to discussions of their own affairs tend to succeed academically. This was also verified during focus group talks, where 80.0 percent of students said their head teachers included them in the decision-making process, while $86.8 \%$ said their head teachers involved them in school governance through their class prefects. This means that the head teachers were complying with the basic education act 2013. PWD require a lot of consultations so that they are not disadvantaged. Because students are significant stakeholders and beneficiaries in the educational process, it was necessary to investigate the impact of including them in critical decisionmaking mechanisms at school.

In terms of parental involvement, the data show that parents were non commital in terms of their level of involvement in their children's performance, therefore the study was unable to draw any conclusions about the influence of their involvement. The more involved parents are in their children's education, the higher the level of involvement, attitudes, and results for kids with disabilities in the entire class. This is because most parents are considerably more familiar with their children than their teachers are. The role of parents in school administration is now codified in the Education Policy, and their tasks include financial mobilization, punishment, and evaluation of the school's performance. The data reveal that head teachers believed that incorporating the school management committee in handling administrative difficulties with a variety of methods had significant effectiveness (0.79). The school management committee should promote the school's and students' interests in order for the students to obtain the finest education possible.

\section{Head Teachers' Performance Monitoring and Participation of Female Learners with Physical Disabilities in Primary Education}

A multiple linear regression was conducted to examine how well head teachers' performance monitoring predicted the level of participation of female pupils with physical disabilities in terms of performance. The performance in percentages of female students with physical disabilities were given by head teachers from 
secondary data for KCPE results from the years 2016 to 2019. The results were as presented in Table 2

Table 2: Performance Results for the Years 2016-2019

\begin{tabular}{lllll}
\hline Performance & $\mathbf{2 0 1 6}$ & $\mathbf{2 0 1 7}$ & $\mathbf{2 0 1 8}$ & $\mathbf{2 0 1 9}$ \\
\hline No of Respondents & 54 & 54 & 54 & 54 \\
Average Performance & $\mathbf{4 7 . 6 \%}$ & $\mathbf{4 5 . 7 \%}$ & $\mathbf{4 5 . 8 \%}$ & $\mathbf{4 6 . 4 \%}$ \\
Standard Deviation & 1.8 & 2.3 & 2.1 & 2.5 \\
Minimum Score & $44.6 \%$ & $40.5 \%$ & $43.2 \%$ & $40.5 \%$ \\
Maximum Score & $51.2 \%$ & $50.3 \%$ & $49.1 \%$ & $50.0 \%$ \\
\hline
\end{tabular}

Table 2 show that the general performance was between $45.7 \%$ to $47.6 \%$ for the years 2016 to 2019 with the minimum being $40.5 \%$ and maximum $51.2 \%$.

To make inferences between the independent variables and the dependent variable, multiple linear regression analysis was used. The regression model was used in this analysis, and the results are seen in Table 3:

$$
Y=\beta_{0}+\beta_{1} X_{2}+\beta_{2} X_{2 .}+\beta_{3} X_{3}+\beta_{4} X_{4}
$$

Where $\mathrm{Y}=$ Dependent Variable $=$ Participation in terms of Performance of Pupils WPD

$\beta_{0}+\beta_{1}=$ coefficients of the independent variables

$\mathrm{Y}=(1.639)+(0.296) \mathrm{X}_{1}+(0.165) \mathrm{X}_{2}-(0.299) \mathrm{X}_{3}+(0.405) \mathrm{X}_{4}+\varepsilon$

Where: $\mathrm{Y}=$ Performance of Female Pupils WPD

$\mathrm{X}_{1}=$ Teacher involvement in pupils' performance

$\mathrm{X}_{2}=$ Pupils' involvement in their own performance

$\mathrm{X}_{3}=$ Parents involvement

$\mathrm{X}_{4}=$ School management committee involvement

$\varepsilon=$ error term

Table 3: Regression Analysis of Head Teachers' Performance Monitoring and Performance of Female Pupils with Physical Disability.

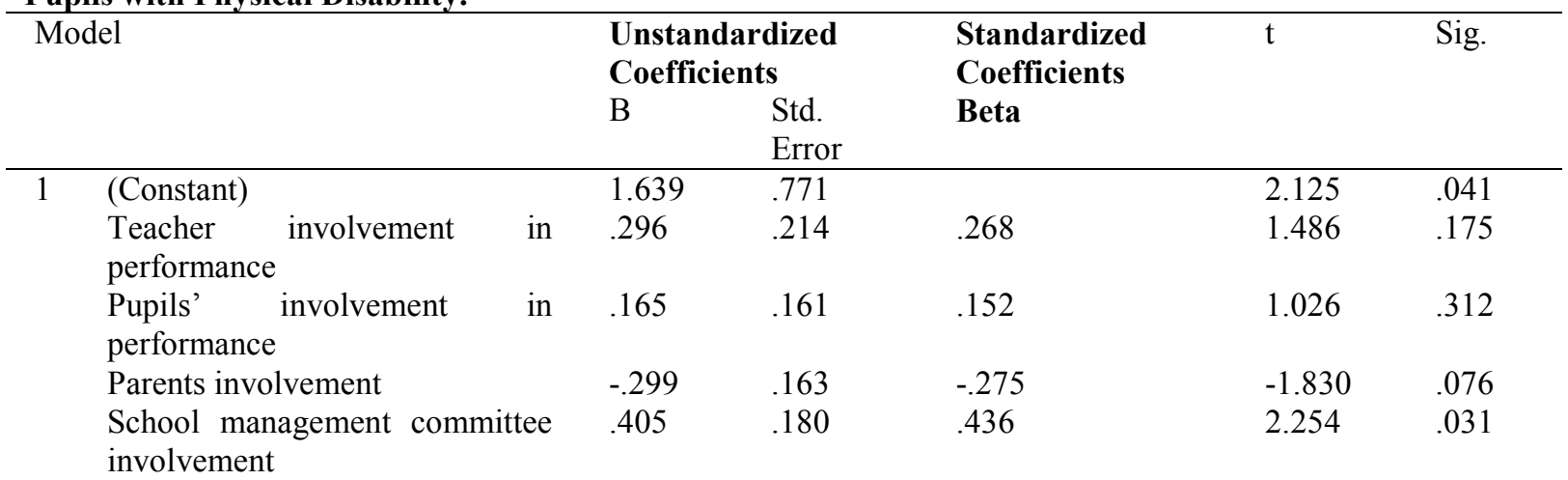

a. Dependent Variable: Performance of female pupils with Physical disability

The findings show a prediction that for every unit advance in teacher involvement in pupils' performance, there was $(29.6 \%)$ progress in performance in examination of female pupils with physical disabilities, every unit advance in pupils' own effort and involvement, there was (16.5\%) progress in performance of female pupils with physical disabilities. Interestingly, the study revealed that for every unit advance in parents' direct involvement in school affairs, there was $(29.9 \%)$ decrease in progress in performance; and for every unit advance in school management committee involvement in addressing school affairs, there was $(40.5 \%)$ progress in performance of female pupils with physical disabilities.

$H_{01}$ : There is no significant relationship between head teachers' monitoring of performance and actual performance of female students with physical disabilities in primary school education.

To test if head teachers monitoring of performance had influence on actual performance of female students with physical disabilities, all the indicators relating to head teachers monitoring of performance were combined and a Pearson moment correlation was applied on the variables and results summarized in Table 4. 
Table 4: Association between Head Teachers Performance Monitoring and Performance of Female Pupils with Physical Disabilities.

\begin{tabular}{lllrl}
\hline & & $\begin{array}{l}\text { Performance } \\
\text { Children } \\
\text { disability }\end{array}$ & $\begin{array}{r}\text { of } \\
\text { with }\end{array}$ & $\begin{array}{l}\text { Head } \\
\text { Performance } \\
\text { Monitoring }\end{array}$ \\
\hline $\begin{array}{l}\text { Performance of Children } \\
\text { with disability }\end{array}$ & $\begin{array}{l}\text { Pearson Correlation } \\
\text { Sig. (2-tailed) }\end{array}$ & 1 & $.462^{* *}$ \\
Head Teachers' Performance & & .003 \\
Monitoring & $\mathrm{N}$ & 53 & 53 \\
& Pearson Correlation & $.462^{* *}$ & 1 \\
& Sig. (2-tailed) & .003 & \\
& $\mathrm{~N}$ & 53 & 53 \\
\hline
\end{tabular}

**. Correlation is significant at the 0.01 level (2-tailed).

According to Table 4, the Pearson's Moment correlation test showed a statistically relevant relationship between head teachers' performance monitoring and real performance of female pupils with physical disabilities $(\mathrm{r}(53)=.462, \mathrm{p} .003)$ based on a crucial alpha value of 0.05 . (0.05). When the actual results are compared to the predicted results based on the null hypothesis, $\mathrm{r}(53)=.462$ shows that there are relationships between the two variables. The $\mathrm{r}$ (correlation) value was translated to $\mathrm{t}$ value using the formula since $\mathrm{N}$ (number of respondents) was greater than 30 :

$$
\mathrm{t}=\mathrm{r} \sqrt{\frac{n-2}{1-r^{2}}}
$$

With a degree of freedom (sample size) of 53 and a confidence level of 99.0 percent, the measured t value was 3.72. Since the estimated value of 3.72 was smaller than the critical value of 2.004 . This suggests that teacher involvement has a positive impact on the inclusion of students with impairments. As a consequence, the null hypothesis that there is no substantial relationship between head teachers' performance monitoring and the enrollment of female students with physical impairments in primary school was rejected.

\section{Discussion}

This paper confirms the quantitative result that head teachers' monitoring of performance influenced participation of female students with physical disabilities in primary school. This finding confirms what Thomson (2011) established, that parents are partners, customers, and instructional assistants. When parents are active in their children's school lives, especially those with physical impairments, they provide the support and knowledge they need to not only do their homework but also develop a lifetime love of learning. As parents and teachers seek to create a dynamic school, Sheldon and Jung (2015) suggest that children's input is critical. According to research, parents who are actively involved in their children's education are more equipped to offer advice or seek outside assistance if they see a child is struggling.

From the findings, it is evident for instance, when a teacher exhibits negative attitude towards pupils; like being lazy and stupid, the pupils become withdrawn and unmotivated thereby affecting their level of participation and performance and all these can be actualized if head teachers has favorable management practices. This was confirmed in their research on the role of teachers in increasing students' classroom participation in universities, Aziz and Kazi (2019) agree that increasing participation does not mean forcing every student to contribute in class; rather, it means providing students with opportunities to learn in a favorable atmosphere and discuss information and topics from their own perspectives. Students' attendance differs, according to Aziz and Kazi (2019), due to variations in academic habits and personalities. As a result, it is the teacher's responsibility to provide a conducive atmosphere for such students to participate.

Koli (2004) agrees that involvement and students' participation in governance through formal meetings amongst themselves, plan activities for school had unprecedented increase in number of schools with consequent increase in enrolments in Britain. On the other hand, Koli (2004) admits that engaging other pupils in decision making had limitations as student prefect system mostly relied on delegated little or no power at all to execute their decisions. Secondly some of the orders enforced by the prefects under the instruction of the head teachers were repressive and punitive to the other pupils. Pascareela and Terenzini (2005) noted that even though student leaders were allowed to exercise leadership by voicing their opinions about their current status of environment, the head teachers still retained the final decision making veto through performance monitoring. The study, therefore, implies that in order to ensure participation of students with disabilities in school affairs, head teachers are encouraged to inculcate changes or course of action shared with pupils. This is in line with Magolda and Ebber, (2006) who argued there is a need of student participation in academic matters to enhance performance monitoring. This study concludes that students are more likely to participate in class if they have a comfortable relationship with their teachers. 
As shown in the study findings, Jack (2004) opines that monitoring of performance is part of participatory decision making and it emanates from behavioral science whose basic tenet is critical player in the management of affairs of learners. Caldwell (2005) feels that the engagement of instructors in monitoring performance is crucial. However, for both students and staff to improve their academic accomplishment, school administrators and instructors need to be able to execute academic performance initiatives with expertise. SMC is important in promoting constructive participation by students with physical disabilities, according to King'oina et al. (2017), because it is actively involved in issues of discipline, guidance, and counseling, as well as attempting to instill a culture of dialogue and inclusive government in classrooms. In order to construct appropriate physical structures in schools, they often need funding from a number of sources. School managers, according to MOEST (2010), must guarantee that boarding facilities follow the rules by ensuring correct implementation.

\section{CONCLUSION AND RECOMMENDATIONS \\ Conclusions}

In conclusion, monitoring of performance is part of participatory decision making and it emanates from behavioral science whose basic tenet is critical player in the management of affairs of learners. Teachers were therefore directly involved in monitoring the performance of female pupils with physical disabilities. Teacher participation in the monitoring of performance is essential, but for both students and staff, school managers and professors require approaches that are competent in implementing academic performance strategies to enhance their academic accomplishments. Consistent instructional supervision by head teachers necessitates constant tracking of students' academic progress as well as classroom effectiveness monitoring. In the classroom, teachers' job is to help pupils build an engaged relationship with the material. Because collaborative curriculum coordination allows teachers to build competences, experience, and ownership of the change, it increases both professional learning and curriculum reform adoption. On the other hand, because the student prefect system largely depended on allocated little or no power to carry out their choices, including other students in decisionmaking may have restrictions. Some of the directives issued by the prefects on behalf of the head teachers were oppressive and punishing for the other students. Despite the fact that student leaders are typically permitted to practice leadership by expressing their views on the present state of their surroundings, the head instructors maintain the final decision-making veto via performance monitoring.

\section{Recommendations}

Based on the study findings, the following recommendations were made:

i. Policy makers implore upon school leadership to ensure that students, especially prefects, participate completely in school governance, as they play a crucial role in the school classroom programmes. Women students with physical impairments should also contribute to the decision making process in order to effectively assist head teachers in the monitoring process.

ii. Policy implementers should encourage head teachers to embrace the inclusion of female pupils with physical disabilities, their parents and the SMC before decision making processes and also involve them in solving problems.

\section{References}

Allida, V., Olela, M., Ogwari, P.\& Minja, O. (2018) Best Practices in Instructional Supervision: A Study of Adventist Secondary Schools in Ranen Conference: Baraton Interdisciplinary Research Journal (2018), 8(Special Issue), pp 1-7

Ballard, T. et al., (2010). Monitoring and evaluation toolkit for junior farmer field life schools. FAO.

Bryman, A. (2004) Social Research Methods. Oxford: Oxford University Press

Eide A., Rooy G, \& Loeb M. (2006) Living conditions among people with disabilities in Namibia: a national, representative study. Oslo, SINTEF.

Gatumu, J. c., Njue, N., \& Chandi, J. R. (2012). Women participation in Miraa (Khat) business and the academic performance of primary school children in Runyenjes Division, Embu, Kenya. International Journal of Humanities andSocial Sciences, 2(17),82-87.

Hsiao, C., Lee, C., \& Tu, L. (2013). The effects of reform in principal selection on leadership behavior of general and vocational high school principals in Taiwan. Educational Administration Quarterly, 49(3), 421450

Huff, J., Preston, C., \& Goldring, E. (2013). Implementation of a coaching program for school principals: Evaluating coaches' strategies and the results. Educational Management Administration \& Leadership, 41(4), 504-526.

Kiprop, C. (2012). Approaches to management of discipline in secondary schools in Kenya. International journal of Research in Management, 2. (2).

Krasnoff, B. (2015). Leadership qualities of effective principals. Northwest Comprehensive Center at Education 
Northwest. Retrieved fromhttp://nwcc.educationnorthwest.org/filesnwrcc/research-brief-leadership qualitieseffective-principals.pdf

Mendels, P., \& Mitgang, D. (2013). Creating strong principals. Educational Leadership, 70 (7), $22-29$.

Mugenda, O.M. \& Mugenda, A.G. (2003). Research Methods: Qualitative andQuantitative Approaches. Nairobi: Acts Pres

Mutweleli, S. (2014). Academic motivation and self-regulation as predictors of academic achievement of students in public secondary schools in Nairobi County, Kenya (Unpublished doctoral thesis). Kenyatta University, Nairobi, Kenya.

Njoroge, P. M., \& Nyabuto, A. N. (2014). Discipline as a factor in academic performanceinKenya.Journal of Educational and Social Research MCSER Publishing, Rome - Italy, 1 (4).

Nyagosia, P. O. (2011). Determinants of differential Kenya Certificate of Secondary Education performance and school effectiveness in Kiambu and Nyeri Counties, Kenya (Unpublished master's thesis). Kenyatta University, Nairobi, Kenya.

Okoko, W. O. (2012). Self-esteem and academic performance of students in public secondary schools in Ndhiwa District, Kenya (Unpublished master's thesis). University of Nairobi, Nairobi, Kenya.

Ongowo, R. 0., \& Hungi, S. K. (2014). Motivational beliefs and self-regulation in biology learning: Influence of ethnicity, gender and grade level in Kenya. Creative Education,5(March), 218-227,

Opini, B. (2018) Barriers to Participation of Women Students with Disabilities in University Education in Kenya Journal of Postsecondary Education and Disability, 25(1), 65 - 79

UNESCO (2010). Education for all global monitoring report; Reaching the marginalized. Paris: UNESCO.

Orodho, A.J. (2017). Techniques of writing research proposals and reports in education and social sciences: An illustrative guide to scholarly excellence. Kanezja publishers, Nairobi, Kenya. ISSBN: 978-9966-7350-0-3.

Orodho, A.J., Ampofo, S.Y., Bizimana, B., \& Ndayambaje, I.(2016). Quantitative Data Management: A step by step guide to data analysis using Statistical Package for Social Sciences (SPSS) Computer software. Kanezja publishers, Nairobi, Kenya. ISBN: 978-9966-7350-3-8.

Orodho, J.A., Nzabalirwa, W., Odundo, P., Waweru, P ., \& Ndayambaje ,I. (2016). Quantitative and Qualitative Research Methods: A step by step guide to scholarly excellence. Kanezja publishers, Nairobi, Nairobi. ISBN: 978-9966-7350-3-8.

Wawire, C. K. (2010). Predictors and consequences of self- handicapping and defensive pessimism among students in selected high schools in Nairobi Province, Kenya (Unpublished doctoral thesis). Kenyatta University, Nairobi, Kenya. 